\title{
Comparison of Decurarization Using Sugammadex and Neostigmine After Rocuronium During Desflurane Anesthesia
}

\author{
Desflurane Anestezisinde Rokuronyum Sonrası Sugammadeks ve Neostigmin ile \\ Dekürarizasyonun Karșılaștırılması
}

\author{
Neriman Güleç', Cafer Mutlu Sarıkaș², Ayșe Nur Yeksan², Sibel 0ba ${ }^{3}$ \\ ${ }^{1}$ Department of Anesthesiology and Reanimation, Bağcular Training and Research Hospital, İstanbul, Turkey; \\ ${ }^{2}$ Department of Anesthesiology and Reanimation, Kafkas University School of Medicine, Kars, Turkey; \\ ${ }^{3}$ Department of Anesthesiology and Reanimation, Şişli Etfal Training and Research Hospital, İstanbul, Turkey
}

\begin{abstract}
AIM: We aimed to compare the two drugs, sugammadex and neostigmine, with regard to reversing neuromuscular blockage provided by rocuronium under desflurane anaesthesia.

METHODS: In this prospective randomized trial, 80 patients with ASA I-III scores were included. The study included the patients having lower abdominal and urological surgery under general anesthesia. In order to evaluate awakening and extubation differences, the participants were assigned into two study groups $S$ and $N$. Group $S$ and N included the participants who were given sugammadex and neostigmine, respectively to reverse the neuromuscular blockage created by rocuronium. In both groups extubation was performed when previously clarified clinical criteria were full and after TOF value reached 0.90. Other than TOF value at decurarization moment, minutely TOF values were also recorded for ten minutes after decurarization. The time period between decurarization and extubation was recorded as the extubation time.

RESULTS: There was no statistical difference between the demographic data. The extubation time in Group $S$ was significantly shorter. The TOF values of Group $S$ at the $2 n d, 3 r d, 4$ th, 5th, 6th, 7th, 8th and 9th minutes were significantly higher than that of Group N.
\end{abstract}

CONCLUSION: In comparison with neostigmine, sugammadex results in faster decurarization and a shorter clinical extubation time following neuromuscular blockage induced by rocuronium administration under desflurane anaesthesia.

Key words: desflurane; neostigmine; randomized controlled trial; sugammadex

\section{ÖZET}

AMAÇ: Desfluran anestezisi altında roküronyum ile sağlanan nöromusküler blokajın düzeltilmesinde nöromusküler blokajın düzeltilmesinde sugammadeks ve neostigmini karșılaștırmayı amaçladık.

Uzm. Dr. Neriman Gülec, Soyak Olimpiakent 5.bölge D3 Blok Da.18 Halkall. Kücükçekmece, İstanbul Tel.05323935231Email.nerimangulec@gmail.com Received: 12.11.2014 - Accepted: 13.05.2015
YÖNTEM: Bu randomize prospektif çalıșmada, ASA skoru I-III olan 80 hasta yer aldı. Çalıșma alt karın ve ürolojik cerrahi geçiren hastaları içerdi. Uyanma ve ekstubasyon farklııklarını ortaya koymak için katıımcılar, rokuronyum verilerek sağlanan nöromusküler blokajı kaldırmak için,sugammadeks ve neostigmin verilen $S$ ve $N$ gruplarına ayrılılar. Her iki grupta da ekstübasyon önceden belirlenmiș klinik kriterler yerine geldiğinde ve TOF 0,90'ı aștığında gerçekleștirildi. Dekürarizasyon sırasında ve sonrasında 10 dakika boyunca dakikalık TOF değerleri kaydedildi. Dekürarizasyon ile ekstübasyon arasında geçen zaman ekstübasyon süresi olarak kaydedildi.

BULGULAR: Demografik data açısından anlamlı fark izlenmedi. Grup S'deki ekstübasyon süresi anlamlı olarak kısaydı. Grup S'nin 2, 3, 4, 5, 6, 7, 8 ve 9. dakika değerleri anlamlı olarak Grup N'den yüksekti.

SONUÇ: Desfluran anestezisi altında roküronyum ile sağlanan nöromusküler blokaj sonrası neostigmine klyasla, sugammadeks ile daha hızı dekürarizasyon ve ekstübasyon zamanı sağlanır.

Anahtar kelimeler: desfluran; neostigmin; randomize kontrollü çalısma; sugammadeks

\section{Introduction}

Muscle relaxants are one of the most common used drugs in anaesthesia practice. They are used to facilitate endotracheal intubation, decrease muscle tonus during surgery, and to facilitate controlled ventilation in special cases in intensive care units ${ }^{1,2}$. Although neuromuscular function can reverse itself, fast and total reversal of neuromuscular blockage is necessary in order to avoid residual paralysis and related side effects.

Although acetylcholineesterase inhibitors are used to reverse neuromuscular blockage, a new drug, 
sugammadex, have been used in clinical practice in recent years for this purpose ${ }^{3}$. Sugammadex is the first and only drug to reverse the effects of steroidal muscle relaxants selectively ${ }^{4}$.

Our aim in this study is to compare sugammadex and neostigmine with regard to extubation periods, TOF (Train-of-four) values, TOF 0.90 times, and complications, in cases where those drugs are used to reverse neuromuscular blockage generated by the administration of $0.6 \mathrm{mg} \mathrm{kg}^{-1}$ rocuronium in patients operated electively under desflurane anesthesia.

\section{Methods}

This prospective, randomized study was performed in Şişli Etfal Training and Research Hospital with ASA (American Association of Anesthesia) I-III risk groups between $01 / 02 / 2012$ and $01 / 04 / 2012$. The study was approved by the ethical committee, and all participants gave informed consents.

The patients with drug intolerance, renal failure, hepatic failure, neuromuscular junction disease, a history of malignant hyperthermia or who are in ASA IV-V risk groups were excluded from the study.

The study included the patients having lower abdominal and urological surgery under general anesthesia. In order to evaluate awakening and extubation differences, the participants were assigned into two study groups. Group $S$ and $\mathrm{N}$ included the participants who were given sugammadex and neostigmine, respectively to reverse the neuromuscular blockage created by rocuronium.

The sample size was calculated with the assumption of a 30\% difference between comparison parameters of the groups. Therefore 40 patients were assigned into each group in order to obtain an alpha error of $5 \%$ and statistical power of $80 \%$.

A standard dose of $2 \mathrm{mg}$ midazolam was administered intravenously about 30 minutes before the operation for the purpose of premedication. Prior to the operation ECG, mean arterial pressure (MAP), peripheral oxygen saturation $(\mathrm{SpO} 2)$, heart rate $(\mathrm{HR})$, and postintubation end-tidal carbon dioxide (EtCO2) (Drager Primus, Drager Medical, Drammen, Norway) were all monitorized for each patient. Neuromuscular monitoring was also performed with a TOF device.

TOF device measures muscle twitch strength to project the depth of muscle relaxation during anesthesia.
It is a combination of an electrical stimulus generator, transducer, muscle response sensor and a monitor. TOF stimulation is delivered every $15 \mathrm{~s}(60 \mathrm{~mA}$, $2 \mathrm{~Hz}$, pulse duration $0.2 \mathrm{~ms}$ ). Following each TOF, the monitor automatically calculates and displays the TOF ratio, that is the magnitude of the fourth twitch of the train (T4) as a percentage of the first twitch $(\mathrm{T} 4 / \mathrm{T} 1) \times 100$.

In this study, for nerve-muscle monitoring, electrodes were placed on the ulnar nerve tract using a TOF device (TOF Watch, Organon Technica, Eppelheim, Germany). Transducers were attached to the thumb and a peripheral heat sensor to the palmar side of the hand. TOF device was calibrated and initial TOF was measured just before the anesthesia induction. Calibration was done by eliciting a number of single twitches: the device automatically sets the response to $100 \%$, and that reference value is stored in memory for the duration of procedure.

A vascular line was obtained using a 16-18 gauge intravenous canulla from the arm free off neuromuscular monitoring. Anesthesia was induced using 5-7 $\mathrm{mg} \mathrm{kg}^{-1}$ thiopental, $1 \mu \mathrm{g} \mathrm{kg}^{-1}$ fentanyl, and $0.6 \mathrm{mg}$ $\mathrm{kg}^{-1}$ rocuronium. Endotracheal intubation was performed 90 seconds after the first dose of rocuronium. Anesthesia was maintained using 5-7\% desflurane and a mixture of $50 \% \mathrm{O} 2$ and $50 \%$ medical air.

Once the decrease of the effect of muscle relaxant was measured with the initiation of spontaneous breathing or muscle twitches, $0.2 \mathrm{mg} \mathrm{kg}^{-1}$ rocuronium was administered and the time of the last dose was recorded. Desflurane was stopped when the surgeon started to close the skin and $2 \mathrm{mg} \mathrm{kg}^{-1}$ sugammadex was administered to the patients in Group $S(n=40)$, while 0.01 $\mathrm{mg} \mathrm{kg}^{-1}$ atropine and $0.03 \mathrm{mg} \mathrm{kg}^{-1}$ neostigmine were administered to the patients in Group $N(n=40)$ for decurarization.

Neostigmine was administered when diaphragmatic movements were seen or when the patient's spontaneous breath effort started clinically at the end of surgery. The neostigmine administration time and the TOF value at this time were recorded by another observer. Extubation was performed when patient was cooperative and followed the commands, could take $50 \%$ of normal tidal volume, open eyes, swallow, hold tongue out of mouth and erect the head for at least five seconds, and when the TOF value exceeded 0.90. The time between decurarization and 
extubation was recorded as the extubation time. The TOF values were measured minutely for ten minutes after decurarization.

Sugammadex was administered to the patients when the surgical procedure was totally completed. The time of sugammadex administration and the TOF value at this time were recorded by another observer. The extubation criteria were the same for sugammadex group. Extubation time and TOF values for ten minutes after decurarization were also recorded for Group S.

The duration of the operation, the duration of anaesthesia, and the dose of fentanyl used were recorded for both groups. All patients were observed for one hour in the recovery room and any complication including residual curarization was recorded.

\section{Statistics}

In addition to the descriptive statistics (mean, standard deviation, median, interquartil range), one way/ irreversible variant analysis was used in the repetitive measurements of the multiple groups. For the comparison of the sub-groups, dual groups and of the qualitative data, the Newman-Keuls multiple comparison test, the independent $t$ test and the chi-square test were employed, respectively. Freidman's test was conducted for repetitive measurement of variable groups which are not showing normal distribution; Dunn's multicomparison test for comparison of subgroups; MannWhitney $U$ test for comparison of binary groups. Results were considered statistically significant when $\mathrm{p}<0.05$.

\section{Results}

There were 20 (50\%) female and 20 (50\%) male participants in Group S. Group N contained 21 (52.5\%) female and 19 (47.5\%) male patients. The demographical characteristics and ASA scores were not significantly different between groups (Table 1).

The duration of the operation and anesthesia, dose of fentanyl, total dose of rocuronium, the cessation time of inhalational anesthetics after the last dose of rocuronium, and the time between the last rocuronium dose and decurarization were not different between groups (Table 2). However, the extubation time for Group $S$ was significantly shorter than that of Group $\mathrm{N}(\mathrm{p}<0.05)$ (Table 3$)$.
The TOF values at the 1 st and 10 th minutes were not different. On the other hand, at the $2^{\text {nd }}, 3^{\text {rd }}, 4^{\text {th }}, 5^{\text {th }}$, $6^{\text {th }}, 7^{\text {th }}, 8^{\text {th }}$ and $9^{\text {th }}$ minutes, the TOF values of Group $\mathrm{S}$ were significantly higher than those of Group $\mathrm{N}$ $(\mathrm{p}<0.05)$ (Table 4, Figure 1).

We did not observe any complication or side effect in the recovery room.

Table 1. Demographic characteristics of patients received sugammadex (Group S) or neostigmine (Group N) to reverse the neuromuscular blockage created by rocuronium

\begin{tabular}{llccc}
\hline & & Group S & Group N & $\mathrm{p}$ \\
\hline Age (year) & & $41.85 \pm 13.88$ & $39.8 \pm 11.84$ & 0.479 \\
Gender & Male & $20(50 \%)$ & $21(52.5 \%)$ & 0.823 \\
& Female & $20(50 \%)$ & $19(47.5 \%)$ & \\
Weight (kg) & & $72.05 \pm 10.47$ & $73.47 \pm 6.9$ & 0.475 \\
ASA group & I & $22(55 \%)$ & $24(60 \%)$ & 0.888 \\
& II & $13(32.5 \%)$ & $12(30 \%)$ & \\
& III & $5(12.5 \%)$ & $4(10 \%)$ & \\
\hline
\end{tabular}

ASA: American Society of Anesthesiologists

Table 2. Intra opertaive findings of patients received sugammadex (Group S) or neostigmine (Group N) to reverse the neuromuscular blockage created by rocuronium

\begin{tabular}{lccc}
\hline & Group S & Group N & $\mathrm{p}$ \\
\hline $\begin{array}{l}\text { Duration of Operation } \\
\text { (sec) }\end{array}$ & $5267.5 \pm 3223.1$ & $4789.5 \pm 3177.13$ & 0.456 \\
$\begin{array}{l}\text { Duration of Anesthesia } \\
\text { (sec) }\end{array}$ & $6328.75 \pm 4473.38$ & $5775.5 \pm 3496.42$ & 0.751 \\
$\begin{array}{l}\text { Dose of Fentanyl } \\
(\mu \mathrm{cg})\end{array}$ & $139.75 \pm 41.96$ & $135 \pm 36.16$ & 0.651 \\
\hline
\end{tabular}

Table 3. Comparison of sugammadex (Group S) and neostigmine (Group $N$ ) after rocurronium to reverse the neuromuscular blockage.

\begin{tabular}{lccc}
\hline & Group S & Group N & $\mathrm{p}$ \\
\hline $\begin{array}{l}\text { Total dose of } \\
\text { rocuronium } \\
\text { (mg) }\end{array}$ & $52.37 \pm 13.01$ & $53 \pm 14.54$ & 0.976 \\
$\begin{array}{l}\text { Time between last } \\
\text { rocuronium dose and } \\
\text { cessation of desflurane } \\
\text { (sec) }\end{array}$ & $3006.75 \pm 1424.83$ & $2799.75 \pm 943.02$ & 0.791 \\
$\begin{array}{l}\text { Time between last } \\
\text { rocuronium dose and } \\
\text { decurarization } \\
\text { (sec) }\end{array}$ & $3481.5 \pm 1499.32$ & $2859 \pm 1093.55$ & 0.076 \\
$\begin{array}{l}\text { Extubation time } \\
\text { (sec) }\end{array}$ & & & \\
\hline
\end{tabular}


Tablo 4. TOF values of the groups given sugammadex (Group S) or neostigmine (Group $N$ ) to reverse the neuromuscular blockage created by rocuronium

\begin{tabular}{lccc}
\hline TOF & Group S & Group N & $\mathrm{p}$ \\
\hline 1st min & $4.9 \pm 6.8$ & $8.6 \pm 14.39$ & 0.149 \\
2nd min & $69.7 \pm 30.14$ & $21.32 \pm 27.31$ & $\mathbf{0 . 0 0 0 1 ^ { * }}$ \\
3rd min & $106.23 \pm 26.23$ & $32.7 \pm 34.58$ & $\mathbf{0 . 0 0 0 1 ^ { * }}$ \\
4th min & $107.48 \pm 21.38$ & $39.05 \pm 32.1$ & $\mathbf{0 . 0 0 0 1 *}$ \\
5th min & $122.29 \pm 21.76$ & $56.11 \pm 38.09$ & $\mathbf{0 . 0 0 0 1 *}$ \\
6th min & $131.08 \pm 21.46$ & $73.85 \pm 46.25$ & $\mathbf{0 . 0 0 0 1 *}$ \\
7th min & $118 \pm 24.22$ & $79.18 \pm 40.14$ & $\mathbf{0 . 0 0 9 ^ { * }}$ \\
8th min & $116.17 \pm 26.36$ & $85.96 \pm 34.44$ & $\mathbf{0 . 0 2 5}$ \\
9th min & $119.67 \pm 24.54$ & $89.07 \pm 30.95$ & $\mathbf{0 . 0 2 5}$ \\
10th min & $119.67 \pm 21.6$ & $106 \pm 20.63$ & 0.237 \\
\hline
\end{tabular}

\section{Discussion}

Traditionally, acetylcholineesterase inhibitors have been used to reverse the effects of non-polarizing muscle relaxants ${ }^{3}$. However, agents in this group possess potential side effects such as pityalism, and may cause a decrease in cardiac output due to their stimulatory effects on muscarinic and nicotinic receptors. The efficacy of these drugs depends on many factors such as acid-base and electrolyte balance, type of anesthesia, the body weight of the patient, and some antibiotics. In addition, a high dose of neostigmine may cause neuromuscular blockage ${ }^{4}$. It is used together with parasympatholytic drugs like atropine and glycopyrrolate in order to prevent its own side effects. Deep blockage cannot be resolved by neostigmine alone; therefore, it cannot be used in emergencies 5 .

Sugammadex is a new pharmacological agent used to reverse the effects of steroidal neuromuscular blockers. It does not have the undesired cholinergic/muscarinic side effects of acetylcholineesterase inhibitors. If given in appropriate doses, it may decrease the duration of effect of rocuronium as of succinylcholine. This property is advantageous in case of difficult intubation or ventilation ${ }^{6}$. It is safer to use succinylcholine which has short-term effect, however combination with sugammadex may cause serious side effects ${ }^{7}$. In appropriate doses, sugammadex reverses neuromuscular blockage, irrespective of anesthetic depth. It does not interfere with the metabolism of acetylcholine, thus it is not necessary to use anticholinergic drugs concomitantly. Furthermore, it has no proven side effects ${ }^{5,6,8}$.

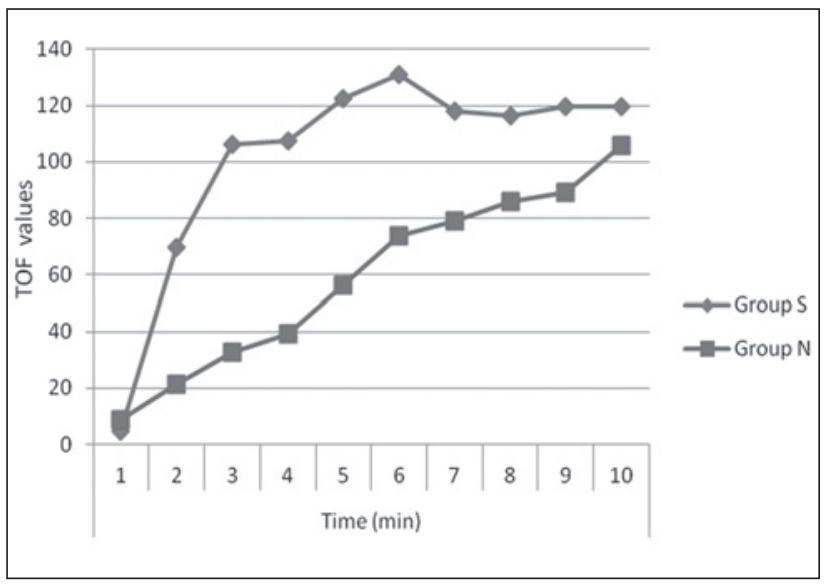

Figure 1. Time dependent comparison of TOF values of patients given sugammadex (Group S) or neostigmine (Group N) to reverse the neuromuscular blockage created by rocuronium.

Although, there are numerous studies dealing with sugammadex, in our study desflurane was used as the anesthetic agent.

Muscle relaxants during general anesthesia leads to residual effects after surgery in about $20-40 \%$ of cases. Residual effects might increase the potential length of hospital stays. Therefore, neuromuscular blockage must be reversed. It is recommended that the TOF value should exceed 0.90 in order to avoid residual blockage and to ensure safe extubation ${ }^{4,6}$. Blobner et al. compared $50 \mu \mathrm{g} \mathrm{kg}^{-1}$ neostigmine and $2 \mathrm{mg} \mathrm{kg}^{-1}$ sugammadex under sevoflurane anesthesia and reported that the time needed to attain a TOF value over 0.90 was 18.6 minutes in neostigmine group and 1.5 minutes in sugammadex group 9 . Similarly, in our study TOF value to exceed 0.90 was three and ten minutes in Group $S$ and $N$, respectively. In addition, there was no residual curarization case in the recovery room.

The recommended dose of sugammadex for immediate reversal of muscle relaxation is between 2 and $16 \mathrm{mg}$ $\mathrm{kg}^{-1}$. Dosage may change according to the depth of the blockage. A dose of $16 \mathrm{mg} \mathrm{kg}^{-1}$ is applied in the case of intense neuromuscular blockage, $4 \mathrm{mg} \mathrm{kg}^{-1}$ for deep neuromuscular blockage, and $2 \mathrm{mg} \mathrm{kg}^{-1}$ for mild neuromuscular blockage ${ }^{5,8}$.

The first study on sugammadex administration was performed using a dose of $0.1-8 \mathrm{mg} \mathrm{kg}^{-1}$ following a dose of $0.6 \mathrm{mg} \mathrm{kg}^{-1}$ rocuronium given to 29 healthy volunteer patients. Muscle relaxation induced by 
rocuronium was reversed by using a $4-8 \mathrm{mg} \mathrm{kg}^{-1}$ dose of sugammadex within two-three minutes ${ }^{10}$. Makri et al. reported that rebound might be seen in rocuronium effects in the case of sugammadex application below a dose of $1 \mathrm{mg} \mathrm{kg}^{-11}$. It was also reported that after a sugammadex dose of over $2 \mathrm{mg} \mathrm{kg}^{-1}$, blockage ceased in less than three minutes. The reversal time of neuromuscular blockage was about 1.1-1.5 minutes in the case of a $4 \mathrm{mg} \mathrm{kg}^{-1}$ use and 1.3-1.7 minutes in the case of a 2 $\mathrm{mg} \mathrm{kg}^{-1}$ use.

During blockage induced by rocuronium, $2 \mathrm{mg} \mathrm{kg}^{-1}$ sugammadex and $50 \mu \mathrm{g} \mathrm{kg}^{-1}$ neostigmine were compared. Sugammadex had a faster reversal effect than neostigmine. In comparative studies, deep neuromuscular blockage performed by rocuronium was compared when $4 \mathrm{mg} \mathrm{kg}^{-1}$ sugammadex (2.9 minutes) and $70 \mu \mathrm{g} \mathrm{kg}^{-1}$ neostigmine (50.4 minutes) were used. The blockage was reversed by sugammadex 17 times faster than by neostigmine, and residual block was not seen in any of the patients ${ }^{3}$. In our study, extubation time was recorded in seconds using a chronometer. Extubation took $130.37 \pm 167.29$ seconds after $2 \mathrm{mg} \mathrm{kg}^{-1}$ sugammadex administration. On the other hand, extubation took significantly longer, $269.1 \pm 1352.1$ seconds, following atropine and neostigmine administration.

In a study performed on morbid obese patients, 35 patients received sugammadex and another 35 patients received neostigmine for decurarization. Mean dose of rocuronium was 87.9 vs $85.6 \mathrm{mg}(\mathrm{P}>0.05)$, mean time to reach $90 \%$ TOF was 2.7 vs $9.6 \mathrm{~min}$ $(\mathrm{P}<0.05)$, and TOF at the post anesthesia care unit was $109.8 \%$ vs $85.5 \%(\mathrm{P}<0.05)$, in Groups SUG and NEO, respectively ${ }^{13}$. Likewise, Woo et al., in their study including 118 patients, showed that time for recovery of the TOF ratio to 0.9 was 1.8 $(1.6,2.0)$ minutes in the sugammadex group and $14.8(12.4,17.6)$ minutes in the neostigmine group $(\mathrm{p}<0.0001)$. These results are also similar with our results. Sugammadex was generally well tolerated in these studies, with no evidence of residual or recurrence of neuromuscular blocker (NMB) effect. Four patients in the neostigmine group were reported with adverse events in one study, possibly indicative of inadequate $\mathrm{NMB}$ reversal ${ }^{14}$. In the sameway, Wu et al. obtained considerable data in a multicentre study performed on 230 Chinese subjects (sugammadex, $\mathrm{n}=119$, neostigmine, $\mathrm{n}=111$ ); and 59 Caucasian subjects (sugammadex, $\mathrm{n}=29$, neostigmine, $\mathrm{n}=30$ ).
They reported; a geometric mean time (95\% CI) for recovery of TOF ratio to 0.9 was $1.6(1.5-1.7) \mathrm{min}$ with sugammadex vs $9.1(8.0-10.3)$ min with neostigmine in Chinese subjects. Corresponding times for Caucasian subjects were $1.4(1.3-1.5) \mathrm{min}$ and 6.7 (5.5-8.0) min, respectively. Sugammadex $2 \mathrm{mg}$ $\mathrm{kg}^{-1}$ was generally well tolerated with no serious adverse events reported. There was no residual NMB or recurrence of NMB effect ${ }^{15}$. Özgün et al. reported that suggammadex was confidently useable for also pediatric patients ${ }^{16}$.

In a randomized, controlled study on adult patients, the reverse effects related to sugammadex were lower than $1 \%$ in all cases and it was advised that this agent was effective and safe ${ }^{17}$. Only one healthy adult patient showed something similar to a slow, allergic reaction, with flushing and tachycardia, following the administration of sugammadex at a dose of $8.4 \mathrm{mg} \mathrm{kg}^{-1}$. Some other studies reported hypersensitivity and anaphlaxis during sugammadex use $\mathrm{e}^{18-21}$. In addition, a bitter taste and coughing due to the high dose of the drug were also reported. Moreover, ECG showed QT interval increase in some patients ${ }^{22}$.

Neostigmine and sugammadex were again compared in terms of hemodynamic effects in patients having neuromuscular blockage using rocuronium or vecuronium. Although sugammadex group had no heart rate changes, neostigmine had significant heart rate increases ${ }^{3,12}$.

Erbaş et al. compared the effects of sugammadex and neostigmine for QT prolongation in rabbits under general anesthesia. Although sugammadex didn't have any influence, neostigmine increased the QT time $^{23}$. Koyuncu et al. reported that extubation, first eye opening and head lift times were shorter in patients given sugammadex. Postoperative heart rates were significantly lower at all times in patients given neostigmine ${ }^{24}$. We did not make a haemodynamic comparison in our study. However, we did not encounter any adverse effects such as bradycardia, tachycardia, hypotension, and hypertension in patients given sugammadex.

In conclusion, in comparison with neostigmine, sugammadex results in faster decurarization and a shorter clinical extubation time following neuromuscular blockage induced by rocuronium administration under desflurane anaesthesia. 


\section{References}

1. Sagır O. Neuromuscular junction and neuromuscular transmission. Turkiye Klinikleri J Anest Reanim-Special Topics 2011;4:1-7.

2. Akha AS, Rosa J, Jahr JS, et al. Sugammadex: cyclodextrins, development of selective binding agents, pharmacology, clinical development, and future directions. Anesthesiol Clin 2010;28:691-708.

3. Jones RK, Caldwell JE, et al. Reversal of profound rocuroniuminduced blockade with sugammadex: a randomized comparison with neostigmine. Anesthesiology 2008;109:816-24.

4. Glinka L, Onichimowski D, Sieniuta P, et al. Sugammadex two years in clinical practice. Anaesthesiol Intens Ther 2010; 3:139-43.

5. Mirakhur RK. Sugammadex in clinical practice. Anaesthesia 2009;64:45-54.

6. Sugammadeks. NDA 22-25. Anesthetic and Life Support Drugs Advision Committee. Available at: http://www. fda. gov/ohrms/dockets/ac/08/slides/2008-4346s1-01-ScheringPlough corebackup. pdf.

7. Chambers D, Paulden M, Paton F, et al. Sugammadex for the reversal of muscle relaxation in general anaesthesia: a systematic review and economic assessment. Health Technol Assess 2010;14:1-211.

8. Booij LHDJ. Cyclodextrins and the emergence of sugammadex. Anaesthesia 2009;64:31-7.

9. Blobner M, Eriksson LI, Scholz J, et al. Reversal of rocuroniuminduced neuromuscular blockade with sugammadex compared with neostigmine during sevoflurane anaesthesia: results of a randomised, controlled trial. Eur J Anaesthesiol 2010;27:874-81.

10. Gijsenbergh F, Ramael S, Houwing N, et al. First human exposure of Org 25969, a novel agent to reverse the action of rocuronium bromide. Anesthesiology 2005;103:695-703.

11. Makri I, Papadima A, Lafioniati A, et al. Sugammadex, a promising reversal drug. A review of clinical trials. Rev Recent Clin Trials 2011;6:250-5.

12. Lemmens HJ, El-Orbany MI, Berry J, et al. Reversal of profound vecuronium-induced neuromuscular block under sevoflurane anesthesia: sugammadex versus neostigmine. BMC Anesthesiol 2010;10:15.
13. Gaszynski T, Szewczyk T, Gaszynski W. Randomized comparison of sugammadex and neostigmine for reversal of rocuronium-induced muscle relaxation in morbidly obese undergoing general anaesthesia. Br J Anaesth 2012;108:236-9.

14. Woo T, Kim KS, Shim YH, et al. Sugammadex versus neostigmine reversal of moderate rocuronium-induced neuromuscular blockade in Korean patients. Korean J Anesthesiol 2013;65:501-7.

15. Wu X, Oerding H, Liu J, et al. Rocuronium blockade reversal with sugammadex vs. neostigmine: randomized study in Chinese and Caucasian subjects. BMC Anesthesiol 2014;14:53.

16. Özgün C, Cakan T, Baltacı B, et al. Comparison of reversal and adverse effects of sugammadex and combination of Anticholinergic-Anticholinesterase agents in pediatric patients. J Res Med Sci 2014;19:762-8.

17. Abrishami A, Ho J, Wong J, et al. Sugammadex, a selective reversal medication for preventing postoperative residual neuromuscular blockade. Cochrane Database Syst Rev 2009; CD007362.

18. Soria A, Motamed C, Gaouar H, et al. Severe reaction following sugammadex injection: hypersensitivity? J Investig Allergol Clin Immunol 2012;22:382.

19. Godai K1, Hasegawa-Moriyama M, Kuniyoshi T, et al. Three cases of suspected sugammadex-induced hypersensitivity reactions. Br J Anaesth 2012;109:216-8.

20. Asahi Y1, Omichi S, Adachi S, et al. Hypersensitivity reaction probably induced by sugammadex. Acta Anaesthesiol Taiwan 2012;50:183-4.

21. Motoyama Y1, Izuta $S$, Maekawa N, et al. Case of anaphylactic reaction caused by sugammadex]. Masui 2012;61:746-8.

22. Dahl V, Pendeville PE, Hollmann MW, et al. Safety and efficacy of sugammadex for the reversal of rocuronium-induced neuromuscular blockade in cardiac patients undergoing noncardiac surgery. Eur J Anaesthesiol 2009;26:874-84.

23. Erbaş M, Toman H, Sahin H, et al. Comparison of effects of sugammadex and neostigmine on QTc prolongation in rabbits under general anesthesia. Acta Cir Bras 2014;29:807-11.

24. Koyuncu O, Turhanoglu S, Ozbakis Akkurt C et al. Comparison of sugammadex and conventional reversal on postoperative nausea and vomiting: a randomized, blinded trial. J Clin Anesth 2015;27:51-6. 